\title{
23
}

\section{U.S. COUNTERTERRORISM POLICY IN YEMEN FROM 2010-2020}

\author{
Luke Hartig
}

In January 2009, al-Qaida's affiliates in Yemen and Saudi Arabia announced a merger and the formation of a new, more formidable group called al-Qaida in the Arabian Peninsula (AQAP). Al-Qaida's Yemen branch had been ratcheting up pressure over the previous year, with attacks on foreign tourists and the U.S. Embassy in Sanaa. But the newly merged group went further, attempting to assassinate one of the closest U.S. counterterrorism partners in Saudi Arabia and partially inspiring two terrorist shootings in the United States. Washington was thrust into action.

Shortly after taking office, the Barack Obama administration moved to lay the groundwork for counterterrorism in Yemen. The administration engaged in intense diplomacy with Yemen's leader, President Ali Abdullah Saleh, to win his unequivocal cooperation in combating the threat. U.S. officials promised extensive aid to Yemeni security forces and other support needed by the impoverished state. In December 2009, the United States reportedly launched multiple airstrikes against AQAP camps in Yemen. ${ }^{1}$ The strikes likely killed dozens of AQAP fighters but also more than three dozen civilians, according to human rights groups. ${ }^{2}$

On Christmas Day 2009, AQAP struck again when Umar Farouk Abdulmutallab attempted to destroy a commercial airliner over Detroit using an explosive device concealed in his underwear. ${ }^{3}$ The device did not detonate, but the failed attack underscored the importance of counterterrorism efforts in Yemen.

As Elisabeth Kendall has outlined earlier in this volume, there were historical and organizational reasons, as well as strong ties to al-Qaida's core organization, that allowed AQAP to become dangerous so quickly. There is no doubt that the political and human terrain also aided AQAP's incubation; the group maintained ties to local tribes and formed in the vacuum created by weak Yemeni security forces. Moreover, Yemen's leader, Saleh, had a spotty record of combating extremism and had ruled for more than 30 years by setting his opponents against one another.

By 2009, Saleh's governing strategy, which he famously called "dancing on the heads of snakes," became unsteady. Sub-national actors, particularly the northern Houthi rebels, increasingly agitated against the central government. AQAP exploited Yemen's environment-its vast ungoverned spaces, traditional role in regional smuggling routes, lingering animosity among the country's disparate regional and sectarian groups from a lengthy civil war in the 1990s, and long borders with Saudi Arabia and Oman-to create an ideal safe haven.

Although the counterterrorism community had long focused on Yemen, it was the failed Christmas Day plot in 2009 that brought the threat home to the American people and fortified the will of policymakers to aggressively combat AQAP. As the government investigated the failed attack, the wheels of U.S. 
policy were set in motion, with senior leaders convening to discuss a wide range of operations and programs the United States could undertake.

U.S. policymakers would focus on five core policy imperatives that would largely define U.S. policy in Yemen for years to come: promoting political and economic reform, developing Yemeni counterterrorism capabilities, disrupting AQAP plotting with lethal action, leveraging regional support for Yemen and counterterrorism efforts, and avoiding over-commitment.

This chapter examines the U.S. campaign against AQAP over four time periods that correspond with the key strategic phases of the conflict: dysfunctional partnership with Ali Abdullah Saleh (2010-2012), President Hadi and a new hope for Yemen (2012-2014), Yemen's unraveling (2014-2017), and a new administration and expanded U.S. military operations (2017-2020).

\section{0-2012: dysfunctional partnership with Ali Abdullah Saleh}

Between the failed Christmas Day attack in December 2009 and the overthrow of the Saleh government in February 2012, the fight against AQAP would reach a fever pitch. AQAP was at its zenith and pursued a multi-pronged strategy, seeking to establish itself as a regional jihadi leader, a top propagandist to disgruntled Muslims in the West, the head of a quasi-state in southern Yemen, and the foremost terrorist threat to the United States. The group called for a regional holy war and a blockade of the Red Sea to prevent shipments to Israel. ${ }^{5}$

AQAP capitalized on limited governance and lingering animosity about the country's predominately northern leadership in southern Yemen to establish a safe haven in the south and to increasingly administer its own territory. They released multiple editions of Inspire, a slick English-language magazine, calling for "lone wolf" attacks in the West and providing various levels of operational instruction to aspiring terrorists. ${ }^{6}$ They persisted in developing increasingly sophisticated concealed explosive devices, most notably a bomb hidden in printer ink cartridges that was intended to bring down a United Parcel Service aircraft en route to the United States in October 2010. ${ }^{7}$

American hopes for addressing the quickly growing threat were channeled through Sanaa and President Saleh, a challenging partner whose government was beset by factionalism, riddled with ties to extremist elements, and unable to provide basic services to its people. On the security side, Yemen needed assistance to build up its counterterrorism capabilities in the face of an emerging threat.

In 2011, the forces of democratization and uprisings against authoritarian governments that came to be known as the Arab Spring emerged in Yemen, leading to major protests in the streets of Sanaa and providing an opening for longstanding political opponents to move against the president. Saleh's long-time but uneasy political ally, Major General Ali Muhsin al-Ahmar, took Saleh's violent crackdowns against protesters as an opportunity to break with the president, ostensibly in support of the protesters but more likely as a way of fortifying his own power. ${ }^{8}$ By spring 2011, Saleh was bowing to the pressure mounting against him and making moves toward stepping down as president.

On June 3, a failed assassination attempt against Saleh, which he blamed on the al-Ahmar family, ${ }^{9}$ left him badly injured and forced him to seek medical treatment in Saudi Arabia. Saleh's politically weak vice president, Abdu Rabbu Mansour Hadi, assumed the presidency in an interim capacity.

During this period, U.S. counterterrorism efforts against AQAP struggled to keep pace with Yemen's political tumult. U.S. operations focused on building up Yemeni security forces and airstrikes against operatives who threatened the United States and its interests. ${ }^{10}$ One of the central priorities was establishing a comprehensive assistance program in support of Yemeni forces. ${ }^{11}$ The U.S. government reviewed and vetted Yemeni security and military units, prepared to deploy Special Operations Forces (SOF) as advisors, ${ }^{12}$ and provided a range of new equipment through the Department of Defense's Section 1206 Counterterrorism Train and Equip authority. 
There was no shortage of challenges. Yemeni forces were beset by factionalism, with different units and elements within units expressing loyalty to Saleh, Muhsin, and various other commanders, all of whom had their own unique relationships with Saleh. The most capable forces, including most of Yemen's fledgling commando units, reported to the president's son, Ahmed Saleh, commander of the Republican Guard, which had traditionally focused on regime protection. The United States would therefore likely achieve the greatest operational return by working with Ahmed, but in so doing, Washington risked empowering the forces most loyal to the Saleh family and the forces the president would most likely rely on to remain in power or suppress political opposition. ${ }^{13}$

Furthermore, Yemen's assistance needs went far beyond its commandos. The Air Force had a terrible record of aircraft maintenance and struggled to field airworthy planes and helicopters from its aging fleet. ${ }^{14}$ Border security was deficient, easing the flow of weapons and fighters into the country and the potential for AQAP to export terrorism far beyond the Arabian Peninsula. ${ }^{15}$ The army also struggled, with factionalism and political struggles undercutting effectiveness. ${ }^{16}$

The United States deployed dozens and eventually more than 100 advisors in the capital and with Yemen's Southern Regional Command. ${ }^{17}$ Washington also provided more than $\$ 200$ million of weapons and equipment to Yemeni forces during 2010-2012. ${ }^{18}$ Although Yemen desperately needed the equipment, the country's dysfunctional armed forces struggled to absorb this massive infusion of new gear. Personnel had to be trained, military leadership had to determine how to incorporate it, and U.S. officials had to push back on the tendency from some Yemeni leaders to keep the gear in pristine condition and not utilize it. The influx of U.S. advisors helped integrate the gear and new tactics into their daily operations.

Nevertheless, with Yemeni wariness of an elevated U.S. military presence and increasing U.S. policymaker concerns over the safety of its people in Yemen, the United States could never deploy enough advisors, dispersed across a wide enough area, to support the full range of forces who needed assistance. By the end of this period, as civil unrest wracked Yemen and removed Saleh from power in 2011, the United States suspended all of its security assistance programs and withdrew most of its advisors. Policymakers concluded that it was too dangerous, and it was too difficult to assess the political loyalty of partner units and whether they might be deployed against protesters or Saleh's political enemies.

At this time, the U.S. targeted killing program was still finding its footing. The U.S. government and Saleh faced significant blowback from the Yemeni public after the reports of civilian casualties from the U.S. airstrikes in December 2009. ${ }^{19}$ U.S. strikes subsequently slowed to a level that would be unlikely to inflict strategic harm on AQAP, with only a single strike against AQAP in $2010,{ }^{20}$ and that strike was reportedly another errant operation that accidentally killed a local official who was meeting with AQAP members in an attempt to negotiate and reconcile with the group. ${ }^{21}$ The Yemeni government had to take additional action to soothe the unrest. ${ }^{22}$

The United States did not conduct another strike until a year later. By the summer of 2011, with Sanaa in turmoil following the medical departure of Saleh, U.S. airstrikes surged, with 9 strikes reportedly conducted between May and September and 12 across the calendar year. Most significant was a strike that killed Anwar al-Awlaqi, AQAP's top propagandist, an increasingly powerful operative, and the first U.S. citizen reportedly targeted for lethal action in the war on terrorism. ${ }^{23}$ Another American operative, Samir Khan, who had produced AQAP's Inspire magazine, was killed alongside al-Awlaqi, ${ }^{24}$ although U.S. officials said he was not intentionally targeted. ${ }^{25}$

\section{2-2014: President Hadi and a new hope for Yemen}

As 2011 drew to a close, a new hope slowly emerged in the form of the acting president, Abd Rabbu Mansour Hadi. A military officer by training, Hadi had been chosen as Saleh's vice president in 1994 for 
two primary reasons: he was a southerner who could theoretically help Saleh claim he was committed to inclusively governing all of Yemen after the civil war, and he would pose no political challenge to Saleh. ${ }^{26}$

In his many years in Sanaa, Hadi had never developed a strong political base of his own. After years of living outside the south and a checkered history of support for southern causes, his ties to southern elites were weak. He quickly grew popular, however, despite his low profile and years of working with Saleh. Many viewed Hadi as a seemingly honorable man with limited ties to the elites who had controlled and exploited Yemen. ${ }^{27}$ Some thought Hadi could bring about change without plunging Yemen into further instability.

With Saleh sidelined from his injuries, and with Yemeni elites uniting to call for Saleh's ouster, Hadi quickly emerged as the best-or the least objectionable — candidate. The Gulf Cooperation Council, a political and economic union comprising Yemen's Arab Gulf neighbors, had become active in Yemen and brokered a deal in which Saleh would formally relinquish power after the 2012 elections and Hadi would be the sole candidate for the presidency to lead Yemen during a two-year transition period. The council committed to helping Hadi, financially and otherwise, through this period and structured a set of political reforms and assistance commitments designed to put Yemen on stronger footing and prepare for open elections in $2014 .^{28}$

As Yemen began to stabilize, however, AQAP continued to grow. AQAP likely saw an opportunity with the Yemeni government focused elsewhere and a small footprint of U.S. trainers and advisors. Throughout spring and summer of 2012, the group seized terrain in southern Yemen. In April 2012, reports emerged that another attempted bombing of an airliner using a concealed explosive device had been thwarted. ${ }^{29}$

Given Yemen's political reform and AQAP's resurgence, the United States made a new commitment to Yemen. Washington would strongly support Hadi, roll back AQAP, and develop a stable and capable partner in a troubled region. To achieve these aims, the top near-term priority was developing a comprehensive assistance program involving security, diplomatic, economic, and humanitarian aid to support the Hadi government and develop weak state institutions.

The United States resumed a comprehensive security assistance program that included a range of activities, from restarting counterterrorism capacity-building to supporting the restructuring of the Yemeni security sector. ${ }^{30}$ SOF returned, ${ }^{31}$ and the U.S. government proposed more than $\$ 37$ million in military aid to augment Yemen's airlift capacity and to equip Yemen's SOF and the Interior Ministry's counterterrorism unit. ${ }^{32}$

Resuming assistance, however, was not as straightforward as the U.S. government might have hoped. Yemen's Ministry of Defense remained deeply dysfunctional, plagued by mismanagement, and factionalized into two enduring camps-Saleh and Ali Muhsin loyalists. Many of the structural reforms proposed would require substantial and long-term commitment. De-factionalizing the ministry by removing Saleh and Muhsin loyalists presented substantial political risk to Hadi, who already lacked support from Yemen's elites and could scarcely afford to alienate Yemen's strong and well-armed political entities.

The Yemeni military had also become a political patronage machine, the dismantling of which presented additional challenges. Most notable were the thousands of Yemeni "ghost soldiers" who received payments despite not serving in the Yemeni military. ${ }^{33}$ Culling the ghost soldiers was critical to improving the ministry's finances but would likely provoke blowback from those losing the payments and their political patrons.

Re-engaging counterterrorism forces also had its challenges. Yemen's civil unrest had altered some of the partners with whom the United States had previously worked. The first task for U.S. advisors was to evaluate the new landscape and assess with whom they could actually work. A bigger challenge, however, was the reduced ability of the U.S. mission in Yemen to accommodate large numbers of personnel. During the 2011 civil unrest, the U.S. mission had consolidated personnel at the former Sheraton hotel to mitigate risk. ${ }^{34}$ 
In September 2012, just two days after the terrorist attack in Benghazi, Libya, protests in Sanaa ostensibly over the Innocence of Muslims film culminated in protesters storming the U.S. Embassy, burning vehicles, and vandalizing the compound. ${ }^{35}$ With the increased danger in Sanaa and a heavy focus from senior U.S. officials on embassy security everywhere in the region after Benghazi, the U.S. mission in Sanaa tightened its security and controlled its personnel levels even more. Each personnel increase was carefully scrutinized. Although the number of military advisors eventually returned to higher levels, late 2011 through most of 2013 were essentially lost years in terms of building Yemeni security capacity.

Nevertheless, the Yemeni military presented some hope. Although the organization was heavily focused on its own internal reforms, it began to take decisive action against AQAP in the south. In concert with southern tribal militias, the military conducted a campaign in 2012 that eventually wrested away AQAP territories and led to major battlefield losses for the group. ${ }^{36}$ It was a huge victory for Washington's Yemeni allies, and U.S. policymakers held out hope that a similar level of military action and local engagement could root AQAP out from its other strongholds.

Yemeni military efforts were complemented by an increase in U.S. airstrikes. The United States executed 56 strikes in 2012 - nearly five times the 2011 total-many of them against AQAP targets in its southern safe haven. ${ }^{37}$ Strikes continued apace in early 2013, reportedly killing the group's top deputy, a former Guantanamo Bay detainee named Said al-Shihri. ${ }^{38}$

Learning from its 2012 losses, AQAP no longer sought to control territory, and instead it regrouped in traditional tribal safe havens and sparsely populated areas. On the rare occasions that the Yemeni military confronted them in these locations, AQAP fought back with refined guerrilla tactics. The group conducted hit-and-run strikes against military bases, carried out an increasing number of terrorist attacks in Sanaa, and then blended back into the population. ${ }^{39}$

AQAP's renewed strength was matched by an elevated role within the global al-Qaida organization. In mid-2013, al-Qaida leader Ayman al-Zawahiri named AQAP amir Nasir al-Wuhayshi the deputy for al-Qaida's worldwide operations. In late July 2013, the U.S. government announced that due to a threat emanating from the Arabian Peninsula, the U.S. presence in Sanaa would be reduced and embassies would be temporarily closed in more than 20 countries. ${ }^{40}$ The losses AQAP had sustained in 2012 appeared to have been recouped. Beyond its own organizational and tactical adaptations, AQAP also seemed to have benefited from a decline in Yemeni military operations after the 2012 campaign, as well as a decline in U.S. airstrikes.

In May 2013, President Obama delivered a speech laying out a new framework that elevated the required standards that must be met before lethal action could be taken against terrorist targets outside areas of active hostilities. ${ }^{41}$ During its first term, the Obama administration grappled with the use of targeted strikes and drone aircraft, and the president believed it was important to establish a set of rules and principles that would address the range of legal and policy issues associated with these operations.

Obama wanted to put the program on a sustainable long-term footing, underpinned by U.S. values and with an eye toward reinforcing and setting new international norms with respect to using force against terrorist targets outside of active warzones. His Presidential Policy Guidance prescribed a detailed interagency process for reviewing proposals for lethal action and directed that lethal force only be used against targets that posed a "continuing, imminent threat to U.S. persons." Strikes were further restricted so that they could only be conducted when capture was assessed to be infeasible and if the relevant operational commander could assess with "near certainty" that civilians would not be harmed in the action. ${ }^{42}$ In practical terms, this meant that U.S. strikes could not be used to provide air support to Yemeni security forces or to attack AQAP elements that were not involved in active plotting against the embassy, the homeland, or other targets where U.S. persons would be present.

Whether due to the new elevated standards, AQAP's improved ability to detect and evade U.S. drones, or other reasons, strikes plummeted following the release of the policy guidance. Yet even the new targeting 
rules could not prevent tragedy. In December 2013, a strike was widely reported to have hit a wedding convoy. ${ }^{43}$ Bound by continued secrecy about specific strikes in Yemen, the U.S. government declined to officially acknowledge or comment on the strike, let alone refute the media accounts. ${ }^{44}$ As the Yemeni population and human rights groups reacted in outrage, the Presidential Policy Guidance reforms did not appear to have eliminated the risk of civilian casualties nor quelled the controversy surrounding the drone program in Yemen.

\section{4-2017: Yemen's unraveling}

By late 2013, it was clear that Yemen's political transition was not progressing according to plan. The twoyear transition period and the National Dialogue Conference, the forum designed to solve the country's political problems during the transition period, were far behind schedule, with major decisions about Yemen's constitutional structure, geographic governance, resource sharing, and economic system unresolved. Gulf economic, security, and technical assistance had not come through as planned, and while Hadi remained popular, the Yemeni population had begun to grow impatient.

During a trip to the United States in 2013, Hadi requested additional aid, and U.S. officials scrambled to increase Washington's support and mobilize international partners. ${ }^{45}$ Hadi leaned into the domestic political work on the transition, moving to quickly but haphazardly conclude the National Dialogue Conference in early 2014, and developed ambitious proposals for Yemen's future government. ${ }^{46}$ Lisa Monaco, Obama's counterterrorism advisor and point person on Yemen, traveled to Yemen and Saudi Arabia in early 2014 to underscore strong U.S. support for the Hadi government and to rebuild momentum around the Gulf Cooperation Council transition. ${ }^{47}$

The troubled transition had begun to alienate two of Yemen's traditionally marginalized groups—southerners and the Houthis - who felt that they had been inadequately represented in the National Dialogue Conference and the structures that would emerge from it. In February 2014, Hadi declared a new federal system for Yemen that organized the country into six regions. ${ }^{48}$ The Houthis objected vociferously that commitments made within the National Dialogue Conference had not been upheld and that they had been placed in a region that was attached to Sanaa and isolated from the Red Sea, virtually ensuring that they would have little autonomy. ${ }^{49}$

Saudi Arabia had also become increasingly antagonistic toward the Houthis, which it viewed as an Iranian-backed threat along its southern border. Yet the history of the Houthis and their relationship with Iran was more complicated than Riyadh alleged. The Houthis followed the Zaydi sect of Shia Islam, which has been described as more closely aligned with the brand of Sunni Islam practiced in Yemen than the Shia Islam practiced in Tehran.

Throughout Yemen's history, Zaydi Muslims have lived largely peacefully alongside their Sunni neighbors in northern Yemen. But spiraling confrontations between Saleh, who benefited from divisions in the country, and an emboldened Houthi movement resulted in multiple wars. The Houthis, perhaps in response to Riyadh's provocations and possibly looking to carve out a mutually advantageous relationship with Iranian government elements that saw opportunity in Yemen, launched rockets into Saudi Arabia and escalated tensions further. In March 2014, the Saudis declared the Houthis a terrorist organization. ${ }^{50}$

While political progress slowed, U.S. counterterrorism programming continued apace. Defense and State Department officials agreed on more than $\$ 69$ million of security assistance in 2014 to provide Yemen with enhanced aerial surveillance and precision strike capabilities. ${ }^{51}$ After the drawdown precipitated by the threat in the summer of 2013, U.S. advisors finally returned and reached personnel levels not seen since before the 2011 protests. Moreover, for the first time in two years, the Yemeni military launched a major offensive against AQAP positions, this time in the rugged al-Mahfid region of Abyan and Shabwa. ${ }^{52}$ 
Reports emerged of U.S. strikes against AQAP training camps, and Yemeni forces moved in shortly thereafter. ${ }^{53}$ The offensive proved far more difficult than the 2012 campaign. AQAP had refined its guerrilla tactics, the terrain was more hospitable to an entrenched insurgency, the local population was far less supportive of the Yemeni Army than the southern tribes had been, and there was no U.S. air support beyond the initial strikes.

Yet the mere fact that Yemeni forces engaged in operations against AQAP outside of Sanaa or Aden was significant and a testament to Hadi's willingness to prioritize counterterrorism even while facing so many other challenges. The United States also continued to conduct drone strikes against AQAP targets, although at a lower pace than before, a total of 17 strikes in 2014 killing 110 combatants and 10 civilians. ${ }^{54}$

Unfortunately, the counterterrorism gains could not conceal the slow-motion disaster developing on the political and economic fronts. The Houthis and southerners continued to simmer in resentment over the political process, and Hadi faced increased pressure from the international community over the crippling structural problems in the Yemeni economy. Clashes between Houthis and Salafis around the Dhammaj area had exacerbated Houthi anger. Yemen's Gulf allies were increasingly focused on the rise of the Islamic State in Iraq and Syria and the intensifying sectarian conflicts with Iran, distracting them from the aid and tremendous work still needed in Yemen.

The World Bank and the International Monetary Fund approved substantial assistance packages, but only if Hadi agreed to implement several economic reforms, the most important of which-an end to fuel subsidies - would ultimately precipitate Hadi's fall. Hadi was eventually convinced and formally ended the subsidies in July 2014. Protests broke out, and demonstrators streamed into the streets of Sanaa, and in some cases armed Houthi youth exploited them. ${ }^{55}$

Hadi was taken aback by the speed and intensity of the outrage, and he quickly moved to tamp down on the discord, reinstate the subsidies, and address the simmering political grievances. ${ }^{56}$ But it was too late. Seeing their opportunity, the Houthis cited Yemeni security force actions to disperse the protesters in early September as a pretense to send armed rebels to Sanaa.

Sanaa had long prepared for a Houthi move on the capital and protected the city with an armored brigade stationed in Amran, just north of Sanaa. ${ }^{57}$ The Houthis clashed with the brigade through the summer of 2014, eventually defeating the unit and killing its commander. Rumors swirled that elements within the Sanaa government or Saleh himself might have allowed for the unit's defeat. ${ }^{58}$ Many of the other reinforcements that Hadi might have called upon remained deployed against AQAP in the eastern part of the country.

The Houthis did not take over Yemen all at once. Their forces were ostensibly present in Sanaa to protect their people from Yemeni government aggression. In the weeks and months that followed, however, they were increasingly emboldened by the lack of concerted resistance and the ease with which they took over Yemen's streets, then its security institutions, and finally the country's national leadership.

The Houthi alliance with Saleh was unexpected as well. Saleh had waged multiple wars against the Houthis during his time in office, but Houthi leadership saw an opportunity in Saleh's overture and were willing to use him to advance their own political gains. Houthi forces, however, killed former President Saleh when he proved no longer useful or trustworthy in December 2017.

The United States scrambled to resolve the crisis. Obama again dispatched Monaco to Yemen and Saudi Arabia in September amid growing Houthi protests, and a United Nations-led process was formed to address the tensions, which would evolve into the United Nations-led political process supported by successive U.S. administrations. ${ }^{59}$ Nevertheless, political resolution proved elusive, and Hadi appeared to be facing a slow-motion coup.

As Hadi's hold on Sanaa weakened, the United States also conducted its first ground operation in Yemen, staging a hostage rescue in the remote deserts of Hadramawt to free American photojournalist Luke Somers. Concern for Somers had grown, particularly after the murders of U.S. hostages in Syria in 
2014. When an opportunity to rescue him materialized, U.S. forces quickly proposed an operation, which Obama approved.

The operation was executed nearly flawlessly, and several hostages held by AQAP were freed, but Somers was not present at the raid site. On December 4, about a week after the initial rescue attempt, AQAP released a video castigating the United States for the failed rescue and threatening to kill Somers if unspecified demands were not met. Facing the threat on Somers' life, U.S. forces developed a new fix on Somers' position and staged another rescue. This time, the operational conditions were more complicated. During the rescue, a firefight erupted, and AQAP captors shot and killed Somers and a South African hostage, Pierre Korkie. ${ }^{60}$

AQAP had failed to secure a ransom or any other concession from the United States or South Africa, but in producing a high-profile drama over the hostages' lives and ultimately murdering them in the face of a U.S. rescue attempt, AQAP had acquired some of the attention and notoriety that the Islamic State had developed with its execution of U.S. hostages several months prior. The possibility of future hostage scenarios and the dangers of trying to free them would remain central to U.S. policymaking and future considerations of in-country programming.

As the political crisis raged, U.S. counterterrorism efforts flagged. Sanaa became increasingly dangerous, with loosely controlled Houthi militants roaming the streets and manning checkpoints and in at least one case firing on a U.S. Embassy vehicle. ${ }^{61}$ Anti-U.S. Houthi rhetoric became increasingly pitched. ${ }^{62}$ Many of Yemen's elite counterterrorism units had come under Houthi influence ${ }^{63}$ or were desperately defending themselves against the Houthis. At the same time, the Houthis actively fought AQAP fighters in key contested areas outside of the capital. ${ }^{64}$

Throughout the fall of 2014, the United States reduced the number of personnel in Yemen out of a concern that the unrest could boil over into a mob siege on U.S. facilities, a violent mishap at a checkpoint, or an intentional Houthi assault on U.S. personnel. With most of the U.S. military's partner organizations in Yemen in crisis, there was little upside to keeping a substantial advisory presence.

In February 2015, the Houthis stormed Hadi's presidential palace, placed him under house arrest, and coerced his resignation (he rescinded his resignation upon later escaping the capital). ${ }^{65}$ Combined with the increasing danger on the streets of Sanaa, U.S. policymakers determined that the risk of maintaining a diplomatic presence in Sanaa outweighed any possible upside, and the United States evacuated all of its personnel from Sanaa in February $2015^{66}$ and all remaining personnel in March. ${ }^{67}$

Saudi and Emirati bombing ramped up within weeks, and it soon became clear that the Saudi war in Yemen was destined to become a quagmire that would lead to a humanitarian crisis for the Yemeni people. AQAP took advantage of the crisis to strengthen its own position. In a return to playbooks from earlier eras, AQAP again seized territory, this time in Hadramawt Governorate. The group established a stronghold in Mukallah in 2015, freeing an estimated 300 fighters ${ }^{68}$ from the local prison and pilfering an estimated $\$ 60$ million or more from the Central Bank in the process. ${ }^{69}$

The new AQAP governance of territory renewed longstanding concerns about geographic safe havens and suggested that it was following the Islamic State's lead by using territory to generate revenue, attract fighters, and plan operations. Islamic State elements also began to emerge in Yemen, presenting a threat to AQAP's monopoly and creating worries of a broader territorial safe haven.

With Yemen under siege from forces internal and external, and with the Saudi bombing campaign proving less discriminate than might have been anticipated given the substantial U.S. aid to Riyadh over the decades, there were certainly pitfalls to continuing with U.S. airstrikes against AQAP. Without a strong partner on the ground, however, the United States had virtually no other alternative.

In the nearly two-year period from the U.S. evacuation in February 2015 to the end of the Obama administration in January 2017, the U.S. government conducted 65 strikes in Yemen. The 43 strikes conducted in 2016 were more than in any year since 2012. ${ }^{70}$ They killed several top AQAP leaders-including 
its amir, Nasir al-Wuhayshi ${ }^{71}$ its religious chief, Ibrahim al-Rubaysh; ${ }^{72}$ and the head of its operations in the south, Jalal al-Balaidi. ${ }^{73}$

Over time, the Obama administration seemed to realize that lethal strikes alone would be insufficient to roll back AQAP's gains. The Saudis remained beset by the challenges of the war against the Houthis, but the United States demonstrated confidence in Emirati forces to take the fight to AQAP. Building on years of cooperation, the United States supported Emirati SOF in launching a campaign against AQAP, focusing on Mukallah, the strategically located capital of Yemen's restive Hadramawt Governorate. ${ }^{74}$

In April 2016, the United States conducted a strike on an AQAP training camp near Mukallah that killed dozens of fighters. Emirati and Yemeni forces-backed by U.S. personnel nearby and supported by Emirati fighter jets overhead-entered Mukallah, killed dozens of enemy fighters, and returned the city and the coastal Hadramawt area to the control of the Hadi government. ${ }^{75}$

Emboldened by their victory, the Emiratis proposed taking additional actions in other parts of the country. By the end of the Obama administration, the Pentagon was preparing options to provide the Emiratis further support in the form of additional military advisors and expanded operational assistance. In other parts of the country, the Saudi-Houthi conflict continued to rage, with the Houthis seemingly empowered with Iranian military materiel and the Saudis increasingly frustrated by the limits of its imprecise air war.

\section{7-2020: a new administration and expanded U.S. military operations}

Little changed on the ground in Yemen with the transition to the Donald Trump administration, but signs of shifts toward a more aggressive U.S. policy emerged almost immediately. Within a week of taking office, the Trump administration authorized a joint U.S.-Emirati ground raid to seize intelligence from an AQAP compound in Yemen. The raid was part of a broader U.S. Central Command plan to increase combined operations with Emirati SOF, both to enable Emirati counterterrorism action and to supplement intelligence collection that had been depleted since the Houthi takeover.

The operation resulted in the deaths of a U.S. Navy SEAL and a dozen or more civilians. ${ }^{76}$ Chief Petty Officer Ryan Owens was the first U.S. service member killed in Yemen in the campaign against AQAP, and although his death marked the beginning of several SOF mishaps that the Trump administration faced during its first several months, the administration was undaunted, and additional ground raids were authorized in subsequent months. ${ }^{77}$

Central Command conducted a surge of more than 80 strikes from February-April 2017 to "degrade the group's ability to coordinate external terror attack operations and limit their ability to hold territory seized from the legitimate government of Yemen and use it as a safe haven for terror plotting." ${ }^{78}$ Following Trump's decision to rescind the Obama drone strike policy and replace it with loosened targeting standards, drone strikes surged yet again, targeting both AQAP and Islamic State elements operating in Yemen. By year's end, the Pentagon reported in excess of 120 airstrikes in Yemen, more than double the number from 2012, the previous high-water mark. ${ }^{79}$

These moves deepened cooperation with partners, and more aggressive actions carried substantial pitfalls. In June, details emerged about what deepened cooperation with the Emiratis entailed. News reports outlined extensive torture of suspected terrorist detainees at Emirati-run facilities in Yemen ${ }^{80}$ Reports suggested that the U.S. military had at least some awareness of the Emirati abuses, and Congressional oversight committees called for investigations to understand the extent of U.S. knowledge or involvement. ${ }^{81}$

The Pentagon disputed reports and suggestions that U.S. forces were aware of the abuses committed by its partners, but the accounts resonated in the region and reinforced popular views of the United States being complicit. The Trump administration's warming relations with Riyadh and unwillingness to criticize the Saudi record in Yemen or its human rights record more broadly only reinforced the narrative against the United States. 
With the war in Yemen dragging into its seventh year and the humanitarian crisis worsening by the day, the U.S. government faced greater pressure than ever to lean on its Saudi and Emirati allies to end the war.

As of late 2020, the war in Yemen was estimated to have killed nearly a quarter of a million people, including more than 3,000 children, through a mix of direct violence and the indirect consequences of the war, according to United Nations assessments. ${ }^{82}$ The war has displaced 3.6 million more. The International Committee of the Red Cross considered Yemen the "world's single largest humanitarian crisis," with over 24 million people - out of a total population of 27 million — in need of aid. ${ }^{83}$

The United Nations Development Program completed a study in late 2019 noting that $75 \%$ of Yemenis were already living below the poverty line and assessing that Yemen was on track to become the poorest country in the world. To date, however, a political resolution to the conflict has proven elusive.

Yet amid all of the violence in the Yemeni civil war, U.S. counterterrorism operations have declined. A U.S. drone strike in late 2017 killed master bombmaker Ibrahim al-Asiri, a major victory that likely reduced AQAP's external attack capabilities and a capstone to a year of elevated strikes ${ }^{84}$ But strikes would slow in the years that followed. Throughout 2019-2020, U.S. strikes averaged fewer than one per month ${ }^{85}$ (although one of those killed AQAP's leader, Qasim al-Rimi). ${ }^{86}$

It is unclear whether the reduced pace of operations was due to a greatly weakened terrorist threat, declining U.S. capabilities, or more nefarious efforts carried out by the Emiratis. ${ }^{87}$ U.S. officials continued to warn of the potential for a terrorist safe haven in Yemen, given its history and high state of unrest, but amid the broader war and humanitarian crisis in Yemen, counterterrorism had become something of an afterthought. ${ }^{88}$

\section{What went wrong?}

Although the United States has successfully prevented AQAP from conducting a major attack against the United States or its allies, its counterterrorism-focused effort in Yemen has been eclipsed by a civil war that has inflicted immense human carnage on the country. The conflict has pushed the Houthis further into the arms of Iran, with financial and military support flowing into the country and threatening prospects for future stability.

America's reputation in the country and the region has been sullied by the Saudi-led bombing campaign, complicating U.S. involvement in post-conflict Yemen and aiding terrorist elements that might seek to capitalize on anti-U.S. sentiment for recruitment and radicalization purposes. The partners that the United States attempted to build within the Yemeni security forces are largely gone- disbanded, killed, or otherwise neutralized during the current conflict. The failure of U.S. policy in Yemen was not the result of any one action but many small missteps that aggregated into a catastrophe. Several key factors merit further examination.

\section{Political reform}

Since 2009, even while combating AQAP, the United States struggled to promote Yemen's long-overdue political, economic, and institutional reform agenda without destabilizing the central government in the process. Implementing such reforms was essential to long-term success in Yemen, and the failure to do so was ultimately the root of the country's undoing. Political and economic reform, however, must always be handled carefully, and Hadi and his international allies may have moved too quickly. At the same time, Hadi's inability to build a national consensus and address Houthi grievances through the National Dialogue Conference provoked their ire, and although the Houthis bear much of the blame for Yemen's collapse, Hadi's bungling of the political process only hastened their aggression.

More broadly, the United States and its international partners largely failed to provide Hadi the development and governance aid he needed. Although such support would not have directly solved Hadi's political 
problems with Yemen's elites, it might have allowed him to show progress and tout his goodwill with the international community to sustain what political progress he made. Yet several of the international pledges of commitment to Yemen as part of the 2012 transition agreement never materialized, and the international push for dramatic economic reforms went too far. When Hadi rolled back the fuel subsidies, the Yemeni streets reacted in outrage, and the Houthis saw their opening.

\section{Counterterrorism capacity building}

Ambitious U.S. capacity-building efforts fared better than political and economic reform efforts, but they also largely failed to meet Yemen's needs. The United States focused on sustainably developing Yemeni counterterrorism capacity without also enabling corrupt or abusive elements within Yemen's security services. But the problem was not one of focus or resources.

The fundamental problem with the capacity building program came down to Yemen's political instability and the difficult security environment. Sensitivity to risk was always at the forefront of policymakers' minds, but it was amplified after Yemen's 2011 political upheaval and the 2012 attack on U.S. personnel in Benghazi. Trainers constantly left; each time they returned, they had to reorient themselves to their Yemeni partners and recalibrate programming. The Yemeni security sector needed a decade-plus uninterrupted commitment. For political and security reasons, the United States was never able to provide that.

\section{Use offorce}

If there is one area where the U.S. counterterrorism campaign in Yemen had greater success, it was through the direct action program. The fact that AQAP has been unable to execute a major attack on the West since 2009 is partially a testament to regional security collaboration, particularly with the Saudis. ${ }^{89}$ Credit must also be given to the role of U.S. airstrikes in removing AQAP's most dangerous and security conscious operatives, men who would have never been killed by the blunt, slow-moving Yemeni military. The death of the elusive master bombmaker Ibrahim al-Asiri in a U.S. airstrike in 2017 is a testament to the effectiveness of the U.S. drone program in Yemen in removing top leaders. ${ }^{90}$

This is not to suggest that U.S. operations were perfectly executed or always strategic. U.S. strike operations seemed to ebb and flow over time, with spurts of strikes followed by long periods without strikes. Sometimes the strikes seemed focused on removing top leadership, while at other times they were more targeted at lower-level fighters or combatants in training. Other times they were used in advance of Yemeni or Emirati military offensives, yet the United States did not provide the kind of sustained air support to ground operations that has proved decisive in supporting partner forces in other theaters, including Libya.

The United States conducted its campaign with increasing precision and discrimination, yet they could not prevent all civilian casualties, and the strikes grew increasingly unpopular. The inability to address Yemeni concerns or provide a transparent accounting of U.S. actions was a failure of policy. Minimal U.S. transparency and candor in response to persistent allegations of civilian casualties fueled popular outrage. The United States may have decreased drone strikes in recent years, but U.S. support to Saudi and Emirati operations in the civil war continues to fuel popular rage against the United States.

\section{Avoiding overcommitment}

Throughout the campaign, policymakers wanted to avoid committing the U.S. military to a third major ground war that would stretch its resources and which the American public would scarcely tolerate, so they relied on small groups of trainers and advisors combined with targeted airstrikes. U.S. officials touted the new approach as a small footprint and carefully scoped method of addressing terrorist threats. 
With a limited commitment, however, the United States never developed the level of infrastructure or range of programming to allow for a sustained, comprehensive, and multi-agency approach to counterterrorism. By the end of the Obama administration, Yemen had plunged deep into civil war with no clear end in sight and a decade or more of reconstruction ahead. Trump faced the same conundrum as Obama: small-footprint approaches to counterterrorism are preferable on a number of levels, but they leave the United States consistently frustrated in its inability to fully execute its objectives.

\section{Regional dynamics}

Throughout the campaign, the United States sought to leverage regional cooperation to support the Yemeni government and combat AQAP while preventing the Gulf states from turning Yemen into a sectarian battlefield over concerns about the Houthis. Yemen's undoing reflects a failure on this front. With the signing of the 2012 Gulf Cooperation Council transition agreement, the council partners all agreed to provide political, economic, or security assistance to the Hadi government. Most of those commitments were only partially or not at all realized.

Then there was the Saudi role in fanning the tensions that would consume Yemen. Saudi Arabia's antagonistic actions toward the Houthis, including designating them as a terrorist group in early 2014, exacerbated longstanding tensions between Saudi Arabia and the rebel group on its southwestern border. To the Saudis, the Houthis were another extension of Shia Iran's tentacles throughout the region-a tenuous proposition before 2015-but Saudi antagonism toward the group may have actually made this a selffulfilling prophecy.

Furthermore, it is not clear that the Saudis did everything they could to marginalize Saleh. The former president spent substantial time in the kingdom following his removal from office, and the Saudis could have potentially done more to convince or coerce him to stay out of Yemeni politics.

\section{Conclusion}

As the Yemen war stretches on, Saudi Arabia's deficiencies have been laid bare. Its political calculations in the run-up to the war were off base; its military, one of the best equipped in the region, has failed to execute even basic operations well; and its military and political leaders have shown little regard for the human consequences of the war.

With the horror of the Yemeni civil war stretching beyond six years and terrorist elements in the country remaining a concern to the United States, U.S. policymakers are in for a tough road ahead. Learning from the past decade is essential if the United States wants to bring about stability on the southern tip of the Arabian Peninsula and keep the American people safe.

\section{Notes}

1 Sudarsan Raghavan, "Yemen Asserts 34 Rebels Killed in Raid on Qaeda," Washington Post, December 18, 2009, http://archive.boston.com/news/world/middleeast/articles/2009/12/18/yemen_asserts_34_rebels_killed_in_ raid_on_qaeda/; “Al-Qaida Fighters Killed in Yemen Air Strikes," Guardian, December 24, 2009, www.theguardian.com/world/2009/dec/24/yemen-strike-al-qaida.

2 Human Rights Watch, Between a Drone and Al-Qaeda: The Civilian Cost of U.S. Targeted Killings in Yemen (New York: Human Rights Watch, 2013).

3 Eric Schmitt and Eric Lipton, “Officials Point to Suspect's Claims of Qaeda Ties in Yemen,” New York Times, December 26, 2009, www.nytimes.com/2009/12/27/us/27terror.html.

4 "Newsmaker: Yemen's Salah, 'Dancing on the Heads of Snakes',' Reuters, September 23, 2011, www.reuters.com/ article/us-yemen-saleh/newsmaker-yemens-saleh-dancing-on-the-heads-of-snakes-idUSTRE78M20X20110923.

5 "Yemen: Qaeda Affiliate Urges Joint Blockade of Red Sea," New York Times, February 9, 2010, www.nytimes. com/2010/02/09/world/middleeast/09briefs-Yemen.html. 
6 Marc Ambinder, “Al Qaeda’s First English Language Magazine Is Here,” Atlantic, June 30, 2010, www.theatlantic. com/international/archive/2010/06/al-qaedas-first-english-language-magazine-is-here/59006/.

7 Peter Finn, "U.S. Official Says 2 Package Bombs Were Intended to Detonate 'in Flight'," Washington Post, November 1, 2010, www.sfgate.com/news/article/Package-bombs-designed-to-detonate-in-flight-3168123.php.

8 “Top Army Commanders Defect in Yemen," Al Jazeera, March 21, 2011, www.aljazeera.com/news/2011/3/21/ top-army-commanders-defect-in-yemen.

9 Sarah Phillips, "Who Tried to Kill Ali Abdullah Saleh?” Foreign Policy, June 13, 2011, https://foreignpolicy. com/2011/06/13/who-tried-to-kill-ali-abdullah-saleh/.

10 Barack Obama, Presidential Letter-2012 War Powers Resolution 6-Month Report (Washington, DC: White House, 2012); Jane Ferguson, "U.S. Military Picks, Trains Yemeni Fighters," CNN, July 14, 2010, www.cnn.com/2010/ WORLD/meast/07/13/yemen.training/index.html.

11 “Gates Backs Big Boost in U.S. Military Aid to Yemen," Reuters, February 22, 2010, https://fr.reuters.com/article/ idUSN22208742.

12 Lolita Baldor, "U.S. Training in Yemen Reflects Wider Quest," Associated Press, September 8, 2010, www.nbcnews. com/id/wbna39062472.

13 Lucas Winter, “The Adaptive Transformation of Yemen's Republican Guard,” Small Wars Journal, March 7, 2017, https://smallwarsjournal.com/jrnl/art/the-adaptive-transformation-of-yemen's-republican-guard. Winter provides an excellent account of the origins and evolution of the Republican Guard, including in the Houthi era.

14 Robert Beckhusen, "The Yemeni Air Force Probably No Longer Exists," War is Boring (blog), March 27, 2015, https://medium.com/war-is-boring/the-yemeni-air-force-probably-no-longer-exists-49f838928670; "Yemen Air Force," Global Security, accessed December 9, 2020, www.globalsecurity.org/military/world/yemen/airforce.htm.

15 Robert F. Worth, "Saudi Border With Yemen Is Still Inviting for Al Qaeda," New York Times, October 26, 2010, www.nytimes.com/2010/10/27/world/middleeast/27saudi.html.

16 Winter, "The Adaptive Transformation of Yemen's Republican Guard."

17 Brian Dodwell and Marielle Ness, "A View From the CT Foxhole: An Interview with Captain Robert A. Newson, Military Fellow, Council on Foreign Relations," CTC Sentinel 8, no. 2 (2015): 1-4.

18 Comprehensive accounting of U.S. security assistance to Yemen is provided at Security Assistance Monitor: https:// securityassistance.org/data/program/military/Yemen/2009/2018/all/Global/.

19 Khaled Abdullah, "Drones Spur Yemenis' Distrust of Government and U.S.," Reuters, October 27, 2010, www.reuters.com/article/us-yemen-usa-qaeda/drones-spur-yemenis-distrust-of-government-and-u-s-idUSTRE69Q36520101027.

20 Peter Bergen et al., "In Depth: America's Counterterrorism Wars," New America, no date. For all discussion of airstrikes and other counterterrorism operations, this chapter relies on either specific media reporting or New America's compilation and analysis of reporting on operations against AQAP.

21 Abdullah, "Drones Spur Yemenis' Distrust."

22 “Air Raid Kills Yemeni Mediator,” Al Jazeera, May 25, 2010, www.aljazeera.com/news/2010/5/25/airraid-kills-yemeni-mediator.

23 Mark Mazzetti, Eric Schmitt, and Robert F. Worth, “Two-Year Manhunt Led to Killing of Awlaki in Yemen,” New York Times, September 30, 2011, www.nytimes.com/2011/10/01/world/middleeast/anwar-al-awlaki-is-killed-inyemen.html.

24 Robbie Brown and Kim Severson, "2nd American in Strike Waged Qaeda Media War," New York Times, September 30, 2011, www.nytimes.com/2011/10/01/world/middleeast/samir-khan-killed-by-drone-spun-out-of-theamerican-middle-class.html.

25 In May 2013, the United States publicly acknowledged its responsibility for killing al-Awlaqi and Khan, along with al-Awlaqi's son and one other U.S. citizen.

26 "Saleh's Successor: Low-Profile Warrior of Consensus in Yemen," Agence France-Presse, February $19,2012$.

27 Peter Salisbury, "Yemen's Quiet President," Al Jazeera, March 2, 2014, www.aljazeera.com/features/2014/3/2/ yemens-quiet-president.

28 International Foundation for Electoral Systems, Next Steps in Yemen's Transition (Washington, DC: International Foundation for Electoral Systems, 2012).

29 Greg Miller and Karen DeYoung, “Al-Qaeda Airline Bomb Plot Disrupted, U.S. Says,” Washington Post, May 7, 2012, www.washingtonpost.com/world/national-security/cia-disrupts-airline-bomb-plot/2012/05/07/gIQA9qE0 8T_story.html.

30 “CENTCOM 2013 Posture Statement," Department of Defense, April 6, 2013. For more details, see http://susris. com/2013/04/06/centcom-2013-posture-statement/.

31 Ken Dilanian and David S. Cloud, “U.S. Escalates Clandestine War in Yemen,” Los Angeles Times, May 26, 2012, https://latimesblogs.latimes.com/world_now/2012/05/washington-escalation-american-clandestine-war-yemenus-troops-.html. 


\section{Luke Hartig}

32 Comprehensive accounting of U.S. security assistance to Yemen is provided at Security Assistance Monitor: https:// securityassistance.org/data/program/military/Yemen/2009/2018/all/Global/.

33 Brian Palmer, "Why Is Yemen So Poor?” Slate, January 4, 2010, https://slate.com/news-and-politics/2010/01/ how-did-yemen-get-so-poor.html.

34 Sheila Carapico, "A New Green Zone in Sanaa," Middle East Report Online, January 1, 2013, https://merip. org/2013/01/a-new-green-zone-in-sanaa/.

35 Mohammed Ghobari, "Yemeni Protesters Storm U.S. Embassy Compound in Sanaa," Reuters, September 13, 2012, www.reuters.com/article/us-yemen-usa-embassy/yemeni-protesters-storm-u-s-embassy-compound-in-sanaaidUSBRE88C0AM20120913.

36 "Yemeni Military Seizes Jihadist Strongholds," Stratfor Worldview, June 13, 2012, https://worldview.stratfor.com/ article/yemeni-military-seizes-jihadist-strongholds.

37 Bergen, "In Depth."

38 Bill Roggio, “AQAP Confirms Deputy Emir Killed in US Drone Strike,” Long War Journal, July 17, 2013, www. longwarjournal.org/archives/2013/07/aqap_confirms_deputy.php.

39 Adrian Shahbaz, "Strategic and Tactical Shift Keeps al-Qaeda Insurgency Alive in Southern Yemen," Terrorism Monitor 10, no. 21 (2012): 4-5.

40 Barbara Starr, "Intercepted al Qaeda Message Led to Shuttering Embassies, Consulates," CNN, August 4, 2013, www.cnn.com/2013/08/04/politics/us-embassies-close/index.html.

41 Barack Obama, Remarks by the President at the National Defense University (Washington, DC: White House, 2013).

42 The Presidential Policy Guidance, with light redactions, was released in 2016, in response to a Freedom of Information Act request that the government had initially contested. For details, see www.justice.gov/oip/foia-library/ procedures_for_approving_direct_action_against_terrorist_targets/download.

43 Human Rights Watch, $A$ Wedding That Became a Funeral (New York: Human Rights Watch, 2014).

44 Lucy Draper, "The Wedding That Became a Funeral: U.S. Still Silent One Year on From Deadly Yemen Drone Strike," Newsweek, December 12, 2014, www.newsweek.com/wedding-became-funeral-us-still-silentone-year-deadly-yemen-drone-strike-291403.

45 Department of State, Remarks with President of Yemen Abdo Rabbo Mansur Hadi Before Their Meeting (Washington, DC: Department of State, 2013).

46 For a comprehensive analysis of the National Dialogue process, see Erica Gaston, Process Lessons Learned in Yemen's National Dialogue (Washington, DC: U.S. Institute of Peace, 2014).

47 Office of the Press Secretary, "Statement by NSC Spokesperson Caitlin Hayden on Assistant to the President for Homeland Security and Counterterrorism Lisa Monaco's Travel to Turkey, Yemen and Saudi Arabia," Obama White House, March 9, 2014, https://obamawhitehouse.archives.gov/the-press-office/2014/03/09/ statement-nsc-spokesperson-caitlin-hayden-assistant-president-homeland-s.

48 "Yemen to Become Six-Region Federation," Al Jazeera, February 10, 2014, www.aljazeera.com/news/2014/2/10/ yemen-to-become-six-region-federation.

49 Yara Bayoumy, "Yemen's Federal Plan a Bold Idea, but Many Hurdles Remain,” Reuters, February 23, 2014 , www. reuters.com/article/us-yemen-politics-analysis/yemens-federal-plan-a-bold-idea-but-many-hurdles-remain-idUS BREA1M05720140223?feedName $=$ worldNews.

50 "Saudi Arabia Designates Muslim Brotherhood Terrorist Group," Reuters, March 7, 2014, www.reuters.com/article/ us-saudi-security/saudi-arabia-designates-muslim-brotherhood-terrorist-group-idUSBREA260SM20140307.

51 Security Assistance Monitor.

52 "Yemen Launches Offensive Against al-Qaeda," Al Jazeera, April 29, 2014, www.aljazeera.com/news/2014/4/29/ yemen-launches-offensive-against-al-qaeda.

53 Mohammed Jamjoon, “Source: 'Massive' Attack Targets al Qaeda in Yemen,” CNN, April 20, 2014, www.cnn. com/2014/04/20/world/meast/yemen-drone-strike/index.html.

54 Bergen, "In Depth."

55 Peter Salisbury, "Yemen Rage Boils Over 'Unlivable' Price Hike," Al Jazeera, August 1, 2014, www.aljazeera.com/ news/2014/8/1/yemen-rage-boils-over-unliveable-price-hike.

56 Danya Greenfield, Yemen: President Hadi's Gamble with the Houthis (Washington, DC: Atlantic Council, 2014).

57 "Yemen's Year of Destruction: The Houthi Takeover of Sanaa," The New Arab, September 21, 2015, https://eng lish.alaraby.co.uk/english/politics/2015/9/21/yemens-year-of-destruction-the-houthi-takeover-of-sanaa.

58 "The Road to Sanaa," Al Jazeera, June 24, 2015, www.aljazeera.com/program/al-jazeera-world/2015/6/24/ the-road-to-sanaa/.

59 Office of the Press Secretary, "Statement by NSC Spokesperson Caitlin Hayden on Assistant to the President for Homeland Security and Counterterrorism Lisa Monaco's Trip to Yemen," Obama White House, 
September 6, 2014, https://obamawhitehouse.archives.gov/the-press-office/2014/09/06/statement-nsc-spokes person-caitlin-hayden-assistant-president-homeland-s.

60 Mark Thompson, "Handicapping the SEAL Raid to Rescue Luke Somers in Yemen,” Time, December 7, 2014, https://time.com/3622579/navy-seal-raid-luke-somers-yemen/.

61 Josh Levs et al., "Yemen's President 'Has No Control' as Houthi Rebels Storm Palace," CNN, January 20, 2015, www.cnn.com/2015/01/20/world/yemen-violence/index.html.

62 Patrick J. McDonnell and Nabih Bulos, “'Death to America! Death to Israel!' Say Houthis in Yemen,” Los Angeles Times, February 20, 2015, www.latimes.com/world/middleeast/la-fg-death-to-america-death-to-israel-say-houthis-in-yemen-20150220-story.html.

63 Craig Whitlock, "Pentagon Loses Track of $\$ 500$ Million in Weapons, Equipment Given to Yemen," Washington Post, March 17, 2015, www.washingtonpost.com/world/national-security/pentagon-loses-sight-of-500-millionin-counterterrorism-aid-given-to-yemen/2015/03/17/f4ca25ce-cbf9-11e4-8a46-b1dc9be5a8ff_story.html.

64 Oren Adaki, "AQAP, Houthis Clash in Central Yemen," Long War Journal, October 16, 2014, www.reuters.com/ article/us-yemen-security/al-qaeda-and-houthis-clash-in-central-yemen-residents-idUKKCN0I41KG20141016.

65 "Yemen's Hadi Declares Houthi Power Grab Illegal," Al Jazeera, February 21, 2015, www.aljazeera.com/ news/2015/2/22/yemens-hadi-declares-houthi-power-grab-illegal.

66 Greg Miller, “U.S. Is Closing Its Embassy in Yemen as Security Concerns Mount,” Washington Post, February 11, 2015, www.washingtonpost.com/world/national-security/us-is-closing-its-embassy-in-yemen-as-security-concerns-mount/2015/02/10/47bf37dc-b16b-11e4-854b-a38d13486ba1_story.html.

67 Katharine Lackey, "U.S. Forces Evacuate Yemen Air Base," USA Today, March 21, 2015, www.usatoday.com/ story/news/world/2015/03/21/yemen-us-military/25138325/.

68 Harriet Alexander, "Al-Qaeda Frees 300 Prisoners in Yemen Jail Break," The Telegraph, April 2, 2015, www.telegraph.co.uk/news/worldnews/middleeast/yemen/11510765/Al-Qaeda-frees-300-prisoners-in-Yemen-jail-break. html.

69 Yaya Fanusie and Alex Entz, Al-Qaeda in the Arabian Peninsula Financial Assessment (Washington, DC: Foundation for the Defense of Democracies, 2017).

70 Bergen, "In Depth."

71 Thomas Joscelyn, “AQAP Confirms Death of Senior Leader,” Long War Journal, June 16, 2015, www.longwarjournal.org/archives/2020/02/white-house-confirms-death-of-aqap-leader.php.

72 Scott Shane, “U.S. Drone Kills a Top Figure in Al-Qaeda's Yemen Branch,” New York Times, April 14, 2015, www. nytimes.com/2015/04/15/world/middleeast/us-drone-kills-a-top-figure-in-al-qaedas-yemen-branch.html.

73 “Top al Qaeda Commander Killed in Yemen Drone Strikes," Reuters, February 4, 2016, www.reuters.com/article/ us-yemen-security/top-al-qaeda-commander-killed-in-yemen-drone-strikes-idUSKCNOVD0G6.

74 William Maclean, Noah Browning, and Yara Bayoumy, "Yemen Counter-Terrorism Mission Shows UAE Military Ambition," Reuters, June 28, 2016, www.reuters.com/article/us-yemen-security-emirates/ yemen-counter-terrorism-mission-shows-uae-military-ambition-idUSKCNOZE1EA.

75 Saeed al-Batati, Kareem Fahim, and Eric Schmitt, "Yemeni Troops, Backed by United Arab Emirates, Take City From Al Qaeda," New York Times, April 24, 2016, www.nytimes.com/2016/04/25/world/middleeast/yemenitroops-backed-by-united-arab-emirates-take-city-from-al-qaeda.html.

76 Eric Schmitt and David E. Sanger, "Raid in Yemen: Risky From the Start and Costly in the End," New York Times, February 1, 2017, www.nytimes.com/2017/02/01/world/middleeast/donald-trump-yemen-commandoraid-questions.html.

77 Eric Schmitt and Helene Cooper, "Navy SEALs Kill 7 Militants in Yemen Raid but Suffer Injuries,” New York Times, May 23, 2017, www.nytimes.com/2017/05/23/world/middleeast/navy-seals-yemen-raid.html.

78 Cheryl Pellerin, “Pentagon Spokesman Updates Iraq, Syria, Yemen Operations,” U.S. Central Command/DoD News, April 24, 2017, www.defense.gov/Explore/News/Article/Article/1161065/pentagon-spokesman-updates-iraqsyria-yemen-operations/.

79 “Update on Recent Counterterrorism Strikes in Yemen," U.S. Central Command, December 20, 2017, www.centcom.mil/MEDIA/PRESS-RELEASES/Press-Release-View/Article/1401383/update-on-recent-counterterrorism-strikes-in-yemen/; Bergen, "In Depth."

80 Maggie Michael, “Inside Yemen's Secret Prisons: 'We Could Hear the Screams',' Associated Press, June 23, 2017, https://apnews.com/article/b2a5ecfd1adb442a86df5bd05bc6599e.

81 "Senators Demand Investigation of Reports of Torture in Yemen," Reuters, June 23, 2017, https://fr.reuters.com/ article/us-yemen-prisons-usa-congress-idUSKBN19E2GZ.

82 “UN Humanitarian Office Puts Yemen War Dead at 233,000, Mostly From 'Indirect Causes',' UN News, December 1, 2020, https://news.un.org/en/story/2020/12/1078972. 


\section{Luke Hartig}

83 Shadi Abusneida, "For Yemenis on the Brink, Aid Funding Gap Spells Disaster," United Nations High Commissioner for Refugees, June 2, 2020, www.unhcr.org/en-us/news/stories/2020/6/5ed631574/yemenis-brink-aid-fundinggap-spells-disaster.html.

84 David Martin, “U.S. Officials Confident Drone Strike Killed Chief al Qaeda Bomb Maker," CBS, August 20, 2018, www.cbsnews.com/news/ibrahim-al-asiri-chief-al-qaeda-bomb-maker-killed-in-u-s-drone-strike/.

85 Bergen, "In Depth."

86 Christopher Miller, "Worldwide Threats to the Homeland," testimony before the U.S. House of Representatives Committee on Homeland Security, September 17, 2020.

87 Luke Hartig, "Full Accounting Needed of US-UAE Counterterrorism Partnership in Yemen," Just Security, December 7, 2018, www.justsecurity.org/61761/full-accounting-needed-us-uae-counterterrorism-partnership-yemen/.

88 Miller, "Worldwide Threats to the Homeland."

89 Greg Miller and Hugh Naylor, "CIA Scales Back Presence and Operations in Yemen, Home of Potent al-Qaeda Affiliate," Washington Post, February 11, 2015, www.washingtonpost.com/world/national-security/cia-scales-backpresence-in-yemen-base-for-potent-al-qaeda-affiliate/2015/02/11/9ad11c52-b219-11e4-827f-93f454140e2b_ story.html.

90 Martin, "U.S. Officials Confident Drone Strike." 